\title{
Ditransitivity and valency change in Teop - a corpus based approach
}

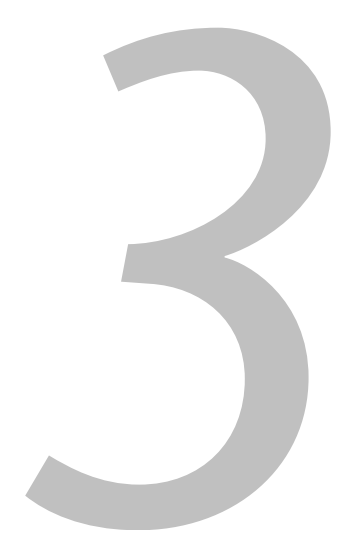

\section{ULRIKE MOSEL}

Seminar für Allgemeine und Vergleichende Sprachwissenschaft, ChristianAlbrechts-Universität zu Kiel, Germany

\begin{abstract}
Das Teop ist eine in Bougainville, Papua Neuguinea, gesprochene ozeanische Sprache, die sich durch eine hohe Anzahl ditransitiver Verben und außerordentlich komplexer Prädikate auszeichnet, deren Valenz durch die Inkorporation von Objekten, seriellen Verben, Präpositionen und einer Applikativpartikel verändert werden kann. Der vorliegende Aufsatz beginnt mit kritischen Überlegungen zum Begriff der Valenz und zu den Methoden der Valenzanalyse und untersucht anschließend anhand eines Korpus von ca. 150000 Wörtern die Valenz einfacher Verben, die Valenz verändernde Funktion der Applikativpartikel und der sog. Dativpräposition sowie die Interaktion von verschiedenen Valenz verändernden Prozessen innerhalb eines einzigen Prädikates. Dabei decken die Valenz verändernden Prozesse die unterschiedliche semantische Rollenstruktur ditransitiver Verben auf.
\end{abstract}

Gleichzeitig werden Leistung und Grenzen des korpusbasierten Ansatzes deutlich.

\section{INTRODUCTION ${ }^{1}$}

Compared to Indo-European languages, Teop, an Oceanic Austronesian language spoken in Bougainville, Papua New Guinea ${ }^{2}$, has a remarkably low number of verbal clause patterns, i.e. intransitive clauses, transitive clauses and ditransitive clauses without any so-called non-canonical subjects or objects, or any kind of differential object marking. This structural simplicity correlates with an extremely complex verbal predicate, henceforth called verb complex (VC), and a pervasive use of ditransitive constructions, which, as can be seen from Margetts' (2007) overview of ditransitive constructions in Oceanic languages, is unusual in this language family.

Rijkhoff, Jan (ed.), Linguistic Typology, Århus: Statsbiblioteket

Tidsskrift for Sprogforskning, årgang 5, 2007

Artikel nr. 3, Mosel, Ulrike, 40 pp.

http://ojs.statsbiblioteket.dk/index.php/tfs/index 
The syntactic functions of arguments and adjuncts are indicated by the order of the constituents that cross-reference morphemes within the VC and articles. Teop is an accusative language that lacks a passive, actors always being encoded as subjects. Common to all core arguments is that they are expressed by noun phrases, whereas nominal adjuncts are marked by prepositions.

Besides the lexical head and tense-aspect markers, a VC can contain an incorporated noun, one or even two serial verbs, pre- and postnuclear adverbs, a discontinuous negation, and an incorporated preposition or the particle $n i$ as a valency changing device (Mosel/Thiesen 2007: section 9.1., Reinig 2004). Since this particle has a function similar to that of applicative affixes in other languages and historically originates from an applicative suffix ${ }^{3}$, we call it the applicative.

Typological research has identified two kinds of applicative derivational affixes (Dixon/Aikhenvald 2000: 13-16):

(1) Applicatives that increase the valency of intransitive verbs by promoting adjuncts to objects.

(2) Applicatives that maintain the number of arguments, but change the semantic roles of objects by simultaneously promoting adjuncts to objects and demoting objects to adjuncts.

Teop deviates from this typological classification: firstly, the applicative, as already mentioned, is not a verbal affix, but a particle within the VC, and secondly, the particle $n i$ is able not only to derive transitive from intransitive VCs, as one would expect, but also to reduce the valency of the VC when it derives transitive from ditransitive VCs by removing the primary object and thereby promoting the secondary object to a primary object. In addition to the applicative ni, Teop can change the valency of VCs by incorporating five prepositions, incorporating the object and using serial verb constructions. ${ }^{4}$

Before exploring ditransitivity and the functions of the applicative, we will discuss the notion of valency and methodological issues in section 2 . and explain our corpus based-approach to research on valency in section 3 . The fourth section describes the clause patterns of Teop and the distinction between arguments and adjuncts, and on this basis we establish, in section 5., the criteria 
for determining the valency of simple verbs in Teop, while in section 6. we investigate the semantic roles of the objects in ditransitive constructions. Finally, the valency-changing function of the applicative is described in section 7. This section also contains a description of the incorporated preposition $k i$, which is similar to applicatives in other languages in that it increases the valency of the VC by making a recipient, addressee or beneficiary adjunct the object of a transitive clause or the primary object of a ditransitive clause. The paper ends with a summary and a few concluding remarks on our corpus-based approach to the analysis of ditransitivity. ${ }^{5}$ Ditransitive causatives are not discussed in this paper. ${ }^{6}$

\section{THE NOTION OF VALENCY - PROBLEMS OF ANALYSIS AND DESCRIPTION}

The notion of valency refers to the number, or to the number and type, of arguments that a verb or, more precisely, a verb form in a particular sense, is required to take in grammatically complete clauses. While some linguists follow Tesnière (1959: 230) and take into consideration only the number of arguments required (Kroeger 2005: 69f., 80), others adopt a wider perspective that includes the syntactic functions and coding properties of arguments, their semantic roles and selectional restrictions, such as 'animate' or 'human', and their pragmatic functions (Dik 1989: 69, Dixon/Aikhenvald 2000: 16, Lazard 1998: 127f., Mosel 1991, Talmy 2007: 131). The concept of valency is sometimes extended to the construction of complex predicates when, as happens in certain kinds of serial verb constructions, the valency of the whole construction is different from the valency of its head (Foley/Van Valin 1984: 197-208; Aikhenvald 2006: 25-27). At a more abstract level, valency can also be regarded as a property of the lexeme 'since the number of alternative valencies different forms of the same lexeme may show is a function of the various grammatical processes the lexeme in question may undergo' (Naess 2007: 123). But note that this application of the concept of valency is not compatible with its extension to constructions (Lehmann 1992: 446).

Since the scope of this paper does not allow us to expand on the various interpretations of the concept of valency in the literature or to compare it with the closely related notions of argument structure and relationality, we now turn to the concept of valency as we use it here. 
A. We distinguish between the valencies of verbs and the valencies of VCs. The valency of a verb becomes evident when it functions as the head of the verb complex without being accompanied by valency-changing elements such as an incorporated object, a serial verb, an incorporated preposition or the applicative:

$\begin{array}{llllll}\text { Eara } & {[\text { kahi }} & \text { asun } & \text { rara }^{7} & e & \text { guu } \\ \text { 1INC.PL } & \text { TAM } & \text { kill } & \text { IMPF:1INC.PL } & \text { ART } & \text { pig }\end{array}$

'We are going to kill a pig.' [Mah. 2.111R]

Here the valency of the verb asun, 'kill', is the same as the valency of the VC [kahi asun rara], 'are going to kill'. But in (2) the valency of the verbal head and the VC are different:

$\begin{array}{lllllll}\text { (2) Enaa } & {[\text { na }} & \text { kikisi } & \text { oha } & u= & \text { nom=] } & \text { an } \\ \text { 1SG } & \text { TAM } & \text { be.strong } & \text { surpass } & \text { OBJ:2SG= } & \text { IMPF:1SG } & \text { 2SG } \\ & \text { 'I am stronger than you.' [Val. 2.10E] }\end{array}$

Whereas the verb kikisi, 'be strong', is intransitive, the VC is transitive due to the serial verb, oha, 'surpass s.o./s.th.'. The object an 2SG is indexed by the crossreferencing object marker $u$. In other words, the serial verb transitivises the VC na kikisi nom, 'am strong'.

B. The valency of a verb or a VC comprises

- $\quad$ The number of obligatory and optional arguments of a clause

- $\quad$ The form and the syntactic function of the arguments

- $\quad$ The semantic roles of the arguments

- $\quad$ The semantic selectional features of arguments

Semantic selectional features will not however be considered in this article. 


\section{THE CORPUS-BASED APPROACH}

Even very large text corpora do not provide data for the full range of clause patterns licensed by particular verbs and they lack sound evidence for determining ungrammatical constructions. Researchers sometimes compensate for this shortcoming of corpora by gathering additional data through tests or by asking native speakers for their intuitions. Herbst (2004: xxxix), for example, reports that even the Bank of English, which contained over 320 million words when the Valency Dictionary of English was completed, "proved insufficient for part of the lexico-grammatical study" so that "some information presented in this dictionary relies exclusively on native speakers' intuition."

The present investigation is based on the Teop Language Corpus (Mosel et al. 2007), which contains the recordings, transcriptions and translations of narratives and procedural texts and dialogues on various topics, and contains no more than 150,000 Teop words. In view of this limitation, it would seem desirable to complement the information that can be extracted from the corpus by elicitation, but we refrained from doing so for the following reasons. Firstly, the Teop Language Corpus has been established within a language documentation project that gives absolute priority to the recording of natural speech events. Secondly, the development of elicitation techniques that can be used in the typical fieldwork situation is still in its infancy. At this stage of our research the present investigation can do no more than provide the groundwork for the design of tests that would provide complementary data for the study of valency in Teop. The purpose of elicitation, when conducted seriously, is not to fill in a few gaps here and there, but systematically to elicit certain kinds of data using tools that have been specifically developed and tested for the research topic in question.

Research on valency in German, which seems to be one of the most thoroughly investigated languages in this respect (Ágel 2000, Ágel et al. 2003), has shown that acceptability tests, in particular, fail to provide reliable data. Different tests may lead to different classifications of one and the same noun or prepositional phrase, and one and the same test clause may be differently evaluated by different native speakers. Furthermore, a test sentence may be judged acceptable or unacceptable for different reasons, so that the test result is not necessarily relevant to the object of the linguist's investigation..$^{10}$ But even if a suitable test is 
found, the question remains as to how many individuals must be asked in order to get statistically reliable results. Under the conditions of linguistic fieldwork on previously undescribed languages this kind of testing may be difficult.

A corpus of the size of the Teop Language Corpus does not permit one to compile a valency dictionary, but it is big enough to identify recurrent clause patterns in terms of the number, the encoding and the meaning of their arguments, and to determine which verbs combine with one or other clause pattern when they are used as the head of a VC and are not accompanied by valency-changing elements such as an incorporated object, serial verbs, an incorporated preposition or the applicative. Moreover, we can distinguish between simple and derived verbs, e.g. siri, 'tear', and tasiri, 'be torn', and observe that certain VC structures correlate with particular clause patterns.

In our attempt to apply a corpus-based approach, we proceed with the analysis of Teop by:

- Identifying the coding strategies by which the types of clause patterns and their constituents are distinguished.

- Describing the valency of a sample of simple verbs.

- Describing the semantic roles of arguments.

- Giving an overview of valency-changing means of expression.

On this basis we then proceed to explore in some detail the functions of the applicative and the incorporated preposition $k i$.

In describing the meaning of clause patterns we will first use the inventory of 'traditional semantic roles' such as agent, patient, theme, recipient, goal, and instrument as metalinguistic descriptive terms and then ask whether the semantic roles associated with the primary object have something in common that distinguishes them from the roles associated with the secondary object. Following Helmbrecht (1998), we assume that the distribution of 'traditional semantic roles' associated with these two syntactic functions is not arbitrary.

\section{TEOP CLAUSE PATTERNS}

Compared to Indo-European languages ${ }^{11}$, Teop has very few verbal clause patterns: intransitive, transitive and ditransitive clauses. Subject, primary object 
and secondary object are distinguished from one another by their sequential order, which cross-references pronominal clitics in the VC, and by the distinction between basic and object articles.

Teop is a configurational language. Noun phrases, adjectival phrases, VCs and prepositional phrases are clearly marked off from one another, each phrase type having its specific markers (e.g. TAM markers in VCs) and a strictly sequential order of elements.

\subsection{Constituent order}

The first position of the clause is held by the topic and the second position by the VC. But when the topic is elided, the VC comes first. The topic can be the subject as in $(1,2,3,4)$, the primary object as in (5) and the secondary object as in (6). Thus the topic is a category that is independent of the syntactic functions of arguments. If the subject is the topic, the primary and the secondary object follow the $\mathrm{VC}(3,4)$.

$\begin{array}{llllllll}\text { SUBJ } & & \text { VC } & & \text { OBJ1 } & & \text { OBJ2 } & \\ \text { E } & \text { Toko } & \text { [paa } & \text { hee }] & \text { bene } & \text { Sookara } & \text { bona } & \text { overe } \\ \text { ART } & \text { Toko } & \text { TAM } & \text { give } & \text { ART } & \text { Sokara } & \text { ART } & \text { coconut }\end{array}$

'Toko gave Sokara the coconut.' [Sia 1.68E]

If it is not the topic, the subject directly follows the VC, and in ditransitive clauses precedes the non-topical object. With the ditransitive verb dao, 'call s.o. s.th.', the primary object, just as in English, is the recipient of the name and the secondary object is the name:

$\begin{array}{lllllll}\mathrm{Me}= & \text { ori } & {[\mathrm{paa}} & \text { dao }] & \text { bari } & \text { bene } & \text { Sirivana } \\ \text { and }= & 3 \mathrm{PL} & \mathrm{TAM} & \text { call } & 4 \mathrm{SG} / \mathrm{PL}^{12} & \text { ART } & \text { Sirivana }\end{array}$

'And they called her Sirivana.' [Mah. 2.148R]

$\begin{array}{llll}\text { (5) } & \text { OBJ1 } & \text { VC } & \text { SUBJ }\end{array}$

A otei vai $[\text { dao } \quad r i=]^{13} \quad$ ori $\quad$ Sitaegoraa

ART man DEM call IMPF:3PL $=3 P L$ Sitaegoraa

'This man, they called Sitaegoraa.' [Mor. 2.15-16R] 
(6)

\begin{tabular}{llllllll} 
OBJ2 & \multicolumn{3}{c}{ VC } & & SUBJ OBJ1 \\
O paku bona ve [pasi hee & ri $]$ & $e$ & bona banoasinae \\
ART feast & DEM but TAM give & OBJ:3PL & 3SG & ART his.relatives
\end{tabular}

'But this feast, he will give to his relatives.' [MLV 1.22R]

Clauses without a topic typically occur at the beginning of narratives where they introduce the topic of discourse by an intransitive clause.

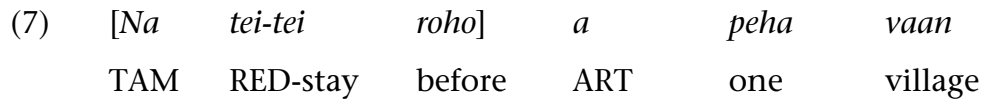

'There once was a village.' [Aro. 12.1R, Aro. 12.1E]

\begin{tabular}{|l|l|l|l|}
\hline TOPIC & & & \\
\hline SUBJ & VC & OBJ1 & OBJ2 \\
\hline OBJ1 & VC & SUBJ & OBJ2 \\
\hline OBJ2 & VC & SUBJ & OBJ1 \\
\hline- & VC & SUBJ & $?$ \\
\hline
\end{tabular}

Table 1: Sequential order of arguments

Adjuncts can occur in the first position of the clause. If none of the arguments functions as a topic, the adjunct is followed by the VC, which is then followed by the subject:

(8)

\begin{tabular}{llllllll} 
ADJUNCT & VC & \multicolumn{9}{c}{ SUBJ } \\
Nabunuu & {$[$ na tii } & roho $]$ & $a$ & peha & vuu tom sinana \\
long.ago & TAM exist & before & ART one cluster & REC mother
\end{tabular}

'Once upon a time there lived a mother with her child.' [Aro. 5.1R]

However, if the clause has a topic, the sentence's initial adjunct is usually followed by the conjunction $m e$, which in other contexts means 'and': 


\subsection{Agreement}

Both subjects and objects are cross-referenced within the VC. While subjects are cross-referenced by the imperfective aspect marker ${ }^{14}$, as shown in $(1,2,5)$, primary objects - with the exception of the 3SG - are indexed by a clitic, the socalled object marker (6). In the VC of the main clause in (10) below, the first clitic, ri, is the object marker that cross-references the topicalised primary object, a abana ... bari, i.e. the recipient of the name, whereas the second clitic, $r i$, is the imperfective aspect marker that cross-references the subject, ori.

(10) OBJ1

\begin{tabular}{|c|c|c|c|c|c|c|}
\hline$[A$ & abana & to & kiikikira & rori & bari] & \\
\hline ART & men & REL & look.after & IMPF:3PL & 4SG/PL & \\
\hline VC & & & & SUBJ & OBJ2 & \\
\hline$[n a$ & $\underline{d a o}$ & $\underline{r i}=$ & $\underline{r i=]}$ & ori & [bona & amarao] \\
\hline TAM & call & $\mathrm{OBJ}: 3 \mathrm{PL}=$ & IMPF:3PL= & 3PL & ART & amarao \\
\hline
\end{tabular}

'The men who look after them, they call (them) the amarao.' [San. 3.2325R]

\subsection{Basic and object articles}

Teop has a complex system of articles, distinguishing between three noun classes as well as between specificity vs. non-specificity, singular vs. plural, and basic vs. object articles (see Table 2). The selection of either a basic or an object article is determined by the following rules, which are explained in Mosel/Thiesen (2007: section 10.4.) and Mosel (in print):

- Subjects and topics are always marked by the basic article.

- Non-topical primary objects ${ }^{15}$ are marked by the basic article if the subject is a first or second person, but if the subject is a third person, primary objects take the object article. 
- Non-topical secondary objects are marked by the basic article only when both the subject and the primary object refer to speech act participants. Otherwise they take the object article.

\begin{tabular}{|c|c|c|c|c|}
\hline \multirow[t]{2}{*}{ articles } & \multirow[t]{2}{*}{ number } & \multicolumn{3}{|c|}{ noun classes } \\
\hline & & e-class & a-class & O-class \\
\hline \multirow[t]{2}{*}{ basic } & sg. & $e$ & $a$ & 0 \\
\hline & pl. & ere, o & 0 & $a$ \\
\hline \multirow[t]{2}{*}{ object } & sg. & bene & bona & bono \\
\hline & pl. & bere & bono & bona \\
\hline \multirow[t]{2}{*}{ non-specific } & sg. & te & ta & to \\
\hline & pl. & $?$ & to & ta \\
\hline partitive & & - & sa & sa \\
\hline
\end{tabular}

Table 2: Articles

In other words, the object article marks an object only when another argument that ranks higher on the SUBJ > OBJ1 > OBJ2 hierarchy is a third person.

$\begin{array}{llllllll}\text { A } & \text { beiko } & \text { tenaa } & {[p a a} & \text { asun= } & u] & \underline{\text { bene }} & \underline{\text { guu }} \\ \text { BASIC.ART } & \text { child } & \text { my } & \text { TAM } & \text { kill= } & \text { IM } & \text { OBJ.ART } & \text { pig }\end{array}$

'My child has killed the pig.' [Aro. 15.134R]

$\begin{array}{lllllll}\text { (12) Enaa } & {[\text { paa }} & \text { dee } & m a= & u] & \underline{e} & \underline{g u u} \\ \text { 1SG } & \text { TAM } & \text { carry } & \text { DIR }= & \text { IM } & \text { ART } & \text { pig }\end{array}$

'I have brought a pig.' [Mat. 1.78E]

In (11) the subject a beiko tenaa, 'my child', is a third person, and consequently the object guu, 'pig', is marked by the object article bene, whereas in (12) the first person subject dictates that guu has the basic article.

The following two ditransitive clauses occur consecutively in the same story. In the first clause both the subject and the primary object of the verb vaasusu, 
'teach', refer to speech act participants, and the secondary object is therefore marked by the basic article:

$\begin{array}{llllllll}\text { (13) Enaa } & \text { [pasi } & \text { vaasusu } & \text { avame=] } & \text { am } & \underline{a} & \underline{\text { meha }} & \underline{\text { taba }} \\ \text { 1SG } & \text { TAM } & \text { teach } & \text { OBJ.IM }= & \text { 2PL } & \text { BASIC.ART other thing }\end{array}$

'I'll teach you another thing.' [Sii. 6.45R]

But in the clause that immediately follows, the teacher and his students are not speech act participants, and the secondary object is therefore marked by the object article.

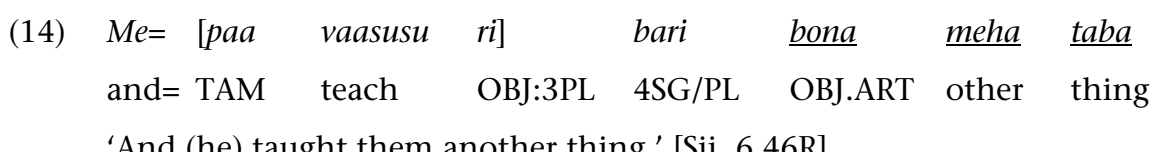

'And (he) taught them another thing.' [Sii. 6.46R]

The clause in (14) also shows that specific participants that can be identified from the context, in this case the teacher, do not need to be explicitly referred to.

\subsection{Arguments and adjuncts}

Arguments differ from adjuncts in that they are expressed by bare noun phrases, and are sensitive to the article selection rule. Among arguments, however, only subjects and primary objects are cross-referenced in the VC. Secondary objects are thus not formally bound to the VC by agreement rules, and this seems to correspond to the semantic roles they express, see section 6 .

\begin{tabular}{|l|c|c|c|c|}
\hline & SUBJ & OBJ1 & OBJ2 & ADJUNCT \\
\hline cross-referenced in VC & + & + & - & - \\
\hline sensitive to article selection rule & - & + & + & - \\
\hline expressed by a NP & + & + & + & - \\
\hline expressed by a PP or a locative phrase & - & - & - & + \\
\hline
\end{tabular}

Table 3: The hierarchy of valency boundedness 
With the exception of certain time adjuncts, adjuncts are expressed by a prepositional or a locative phrase. Locative phrases are similar to noun phrases, but like place names they do not have articles:

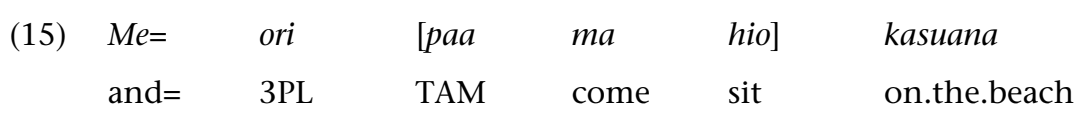

'And they came and sat on the beach.' [Sii. 6.24R]

Furthermore, adjuncts are never positioned closer to the VC than any of the arguments. For examples see (37), (41), (42), (43) and (44) below, and Mosel/Thiesen (2007: section 10.8.).

\section{VALENCY OF SIMPLE VERBS}

The table below gives examples of strictly intransitive, transitive and ditransitive verbs, i.e. verbs that in our corpus occur only in intransitive, transitive or ditransitive clauses respectively, unless they are combined with some valencychanging means of expression.

\begin{tabular}{|l|l|l|}
\hline intransitive verbs & tamaka & 'be sad' \\
\hline transitive verbs & dee & 'carry, bring, take s.th.' \\
\hline ditransitive verbs & hee & 'give s.o. s.th.' \\
\hline
\end{tabular}

Table 4: Valency of simple verbs

Teop has many ambitransitive verbs, i.e. bivalent verbs with an optional object and trivalent verbs with an optional secondary object, or with both an optional primary and an optional secondary object. The verb nahu, 'cook (s.th. with s.th.)', for example, is used in intransitive, transitive and ditransitive clauses without valency-changing morphology so that its valency is evident. Likewise the valency of the verb asun, 'kill s.o. (with s.th.)', is evident since it is used in both transitive and ditransitive clauses, but is intransitivised by the incorporation of the noun $a b a$, 'person', in intransitive clauses, e.g. asun $a b a$, 'kill people, be a murderer'.

However, when an action verb such as kino, 'write', occurs only in intransitive and transitive clauses, we do not know whether it can also license a secondary 
object denoting an instrument. Many action verbs do, but we do not know how productive this clause pattern is.

For example, we assume that dee, 'carry, bring, take s.th.', is strictly transitive because it never occurs with a secondary instrument object and because 'carry s.th. by the means of s.th.' is expressed by verbs that denote a certain way of carrying things:

$\begin{array}{lll}\text { hoihoi } & \text { v.t., } & \text { 'carry s.th. in a basket' } \\ \text { kae } & \text { v.t., } & \text { 'carry s.th. with a handle' } \\ \text { pate } & \text { v.t., } & \text { 'carry s.th. in the arms' } \\ \text { vateen } & \text { v.t., } & \text { 'carry s.th. in a backpack' } \\ \text { vaadee } & \text { v.t., } & \text { 'carry s.th. on a pole between two people' }\end{array}$

We can also exclude the possibility that dee, 'carry, take, bring' is similar to hee, 'give', in taking the recipient as its primary object and the theme as its secondary object. In such contexts, dee, 'carry, take, bring', always combines with a valency-changing marker, e.g. dee ki, 'bring s.o. s.th.': see below section 7.2., examples $(45,46)$. By contrast hee, 'give s.o. s.th.', is unmarked in ditransitive clauses, but marked when the recipient is not specified, as in hee ni v.t., 'give, donate s.th.': see below, section 7.1., example (32). Thus it is these patterns of markedness that allow us to determine the valency of particular verbs.

\begin{tabular}{|l|l|l|l|}
\hline \multicolumn{2}{|l|}{} & in transitive clauses & in ditransitive clauses \\
\hline dee & 'carry, bring, take' & unmarked & marked \\
\hline hee & 'give' & marked & unmarked \\
\hline
\end{tabular}

Table 5: Markedness patterns of dee, 'carry, bring, take' and hee 'give'

Similarly, we assume that tamaka, 'be sad', and other verbs of emotion are intransitive because they are used transitively only with the applicative, e.g. tamaka ni, 'be sad about, because of'; mararae, 'be happy with'; hevee ni, 'be angry at', etc. 


\section{SEMANTIC ROLES IN DITRANSITIVE CONSTRUCTIONS}

Like many other languages, Teop has ditransitive clauses in which the primary object refers to a recipient and the secondary object to a theme. But it also has clauses with a patient as the primary object and an instrument as a secondary object - a type of ditransitive clause that has not yet been reported in any other language (Andrej Malchukov, p.c.). The following examples show haihai, 'help', and $n a h u$, 'cook', in intransitive, transitive and ditransitive clauses:

haihai, 'help (s.o. by giving him/her/them s.th.)':

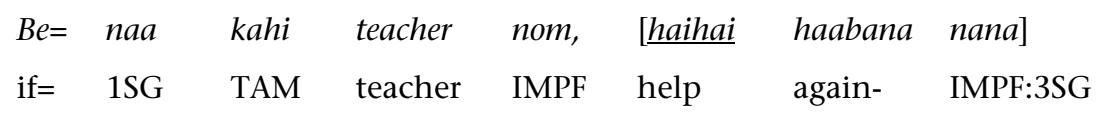

'If I am a teacher, (it) will be of help again.' [Pur. 1.583R]

(18)

$\begin{array}{lllllll}\text { Enaa } & \text { pasi } & \text { haihai } & \text { bata }= & u & \text { nom=] } & \text { an } \\ \text { 1SG TAM help along= } & \text { OBJ:2SG } & \text { IMPF:1SG= } & \text { 2SG } \\ \text { 'I will help you.' } & \text { [Pur. 1.557R] }\end{array}$

$\begin{array}{llll}\mathrm{Me}= & \text { ori } & {[\text { nomaa }} & \text { vai }] \\ \text { and }= & \text { 3PL } & \text { come } & \text { now }\end{array}$

$\begin{array}{llllllll}\text { [haihai } & \text { ara=]- } & \text { ara } & \text { bona } & \text { maa } & \text { si } & \text { taba } & \text { vai } \\ \text { help } & \text { OBJ:1INC.PL= } & \text { 1INC.PL } & \text { ART } & \text { PL } & \text { DIM } & \text { thing } & \text { DEM }\end{array}$

'And they are now coming to help us with these little things.' (implying that 'these little things' are given) [Vos. 1.26R]

nahu 'cook (s.th. with s.th.)':

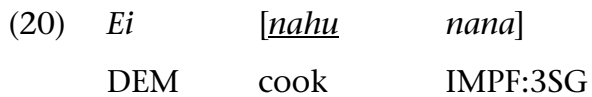

'She cooks (while the man is doing other things).' [MLV 2.41R] 
DitRANSITIVITY AND APPLICATIVE CONSTRUCTIONS IN TEOP - A CORPUS-BASED STUDY

(21) be= nam [tau nahu $]$ a iana

when= 1PL.EXC TAM cook ART fish

'When we are about to cook the fish' [Hel. 5.8R]

(22) $a=$ re $[m a$ nahu $]$ a guu vai bona tahii

1INC.PL $=$ CONJ come cook ART pig DEM ART saltwater

'(You must fetch some saltwater) so that we can cook this pig (with) the saltwater.' [Mat. 1.68R]

The verb asun, 'kill s.o. (with s.th.)', is found only in transitive and ditransitive clauses:

$\begin{array}{llllll}\text { Enaa } & {[\text { kahi }} & \underline{\text { asun }}= & u- & \text { nom }=] & \text { an! } \\ \text { 1SG } & \text { TAM } & \text { kill }= & \text { OBJ:2SG } & \text { IMPF:1SG }= & \text { 2SG }\end{array}$

'I am going to kill you!' [San. 1.107R]

(24) $M e=$ ori $[$ paa asun $]$ bari

and $=\quad 3 P L \quad$ TAM kill $\quad 4 S G / P L$

bona maa taba vaasuasun te- ori

ART PL thing fight PREP- 3PL

'And they killed him with their weapons.' [Sii. 6.308E]

The examples given above show recipient-theme and patient-instrument constructions. Below we give some additional examples that are representative of the semantic roles associated with objects in ditransitive clauses (ditransitive causatives, e.g. vaa'ani, 'let s.o. eat s.th.', are not considered in this paper). 


\begin{tabular}{|c|c|c|c|}
\hline verb & & semantic role of OBJ1 & semantic role of $\mathrm{OBJ} 2$ \\
\hline hee & 'give s.o. s.th.' & recipient & theme \\
\hline$d a o$ & 'call s.o. s.th.' & recipient & theme \\
\hline koa & 'pour s.o. s.th. (to drink)' & recipient & theme \\
\hline hivi & 'ask s.o. s.th.' & addressee & question \\
\hline bana & 'spread s.th. on s.th' & goal & theme \\
\hline havi & 'rub s.th. on s.o./s.th.' & goal & theme \\
\hline koma & 'pour s.th. on s.th.' & goal & theme \\
\hline ramana & 'sprinkle s.th. on s.th.' & goal & theme \\
\hline tasu & 'throw s.th. at s.o./s.th.' & goal & theme \\
\hline asun & 'hit, kill s.o. with s.th.' & patient & instrument \\
\hline nahu & 'cook s.th. with s.th.' & patient & instrument \\
\hline paku & 'make s.th. from s.th.' & patient & instrument \\
\hline gono & 'get s.th. with s.th.' & theme & instrument \\
\hline
\end{tabular}

Table 6: The semantic roles of the primary and the secondary object

The distribution of semantic roles between the primary and the secondary object is certainly not arbitrary, although at first sight a recipient, a goal and a patient do not seem to have much in common. Moreover, we see that with some verbs (bana, 'spread', havi, 'rub', etc.) the theme is a secondary object, while with gono, 'get', it is the primary object. Leaving hivi, 'ask', and gono, 'get', aside for a moment, the semantic relationship between the two objects seems to be similar in all constructions: while the primary object refers to a stationary person or thing towards which the action is directed, the secondary object refers to something that is moved and comes into contact with the primary object's referent. 
The clause pattern of hivi, 'ask', could be explained as a metaphorical extension of this pattern, with the question or the content of the question being understood as an object that is moved from the speaker/agent, to the hearer/recipient:

\begin{tabular}{|c|c|c|c|c|c|c|}
\hline (25) & [hivi & vai] & anaa $^{16}$ & bono & vaabuaku & $o$ \\
\hline DEM & ask & now & 1SG.OBJ & ART & second & ART \\
\hline
\end{tabular}

'Here, (she) then asked me the second question.' [Pur. 2.246R]

However, the ditransitive theme-instrument construction of gono, 'get s.th. by using s.th. as an instrument', requires an explanation of a different sort because both the primary and the secondary object refer to entities that are moved:

\begin{tabular}{|c|c|c|c|c|c|c|c|c|}
\hline (26) & re & {$[p a a$} & gono & vaha] & $o$ & vasu & $o$ & hihivaa \\
\hline $1 \mathrm{INC}=$ & $\mathrm{CONJ}$ & TAM & get & again & ART & stone & ART & hot \\
\hline bono & kakap & & & & & & & \\
\hline ART & tongs & & & & & & & \\
\hline
\end{tabular}

'Then we get the hot stones again with the tongs.' [Hel. 1.51R]

Since the theme is expressed by the primary object and instruments are never found in this function - they occur as objects only in applicative constructions we assume that the theme is conceived as being more closely bound to the action. ${ }^{17}$

The selection of clause patterns is not fully predictable. There is, for example, the transitive verb of communication sue, 'say s.th.', that in contrast to hivi, 'ask s.o. s.th.', requires the message to be referred to by the direct object, e.g. 
ULRIKE MOSEL

(27)

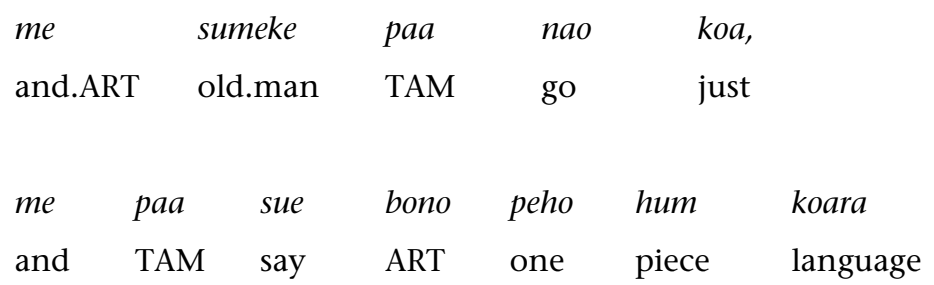

'and the old man only went and said one word.' [Sha. 1.113R]

If the recipient of the message is to be expressed, sue, 'say', must be combined with the incorporated preposition $k i$, 'to': see below, section 7.2.

\section{VALENCY CHANGING}

At word level, causatives are derived by the prefix vaa-, anti-causatives be the prefix $t a$ - and reciprocals by the prefix $v a$ - and by reduplication:

\begin{tabular}{|l|l|l|l|}
\hline \multicolumn{2}{|l|}{ simple form } & \multicolumn{2}{l|}{ derived form } \\
\hline kiu & v.i. 'work' & vaa-kiu & v.t., 'make s.o. work' \\
\hline ani & v.t. 'eat (s.th.)' & vaa-ani & v.dt., 'make s.o. eat s.th.' \\
\hline siri & v.t., 'tear s.th.' & ta-siri & v.i., 'be torn' \\
\hline asun & v.t., 'kill s.o.' & va-asu-asun & v.i., 'kill each other' \\
\hline
\end{tabular}

Table 7: Valency-changing morphology

At phrase level, i.e. within the verb complex in Teop we find:

- $\quad$ The applicative $n i$

- Preposition incorporation as a valency-increasing or rearranging device

- Object incorporation as a valency-reducing device

- Serial verb constructions as a valency-increasing device

In the following we will examine only the applicative (section 7.1.) and the incorporation of the preposition $k i$ (section 7.2.), and give a few examples of multiple valency-changing operations (section 7.3.). 


\subsection{The applicative}

The applicative changes the valency of intransitive and ditransitive verbs. With intransitive verbs, it increases the valency of the VC. Depending on the meaning of the verb, the applied object denotes the patient, the stimulus of an emotion, the message, the cause or the instrument:

\begin{tabular}{|l|l|l|l|l|}
\hline \multicolumn{2}{|l|}{ intransitive verb } & \multicolumn{2}{l|}{ verb with applicative } & semantic role of OBJ1 \\
\hline kavuhu & 'spit' & kavuhu ni & 'spit s.th. out' & patient \\
\hline mararae & 'be happy' & mararae ni & 'be happy about' & stimulus \\
\hline moroko & 'talk' & moroko $n i$ & 'talk about' & message \\
\hline mate & 'die' & mate ni & 'die of' & cause \\
\hline pita & 'walk' & pita ni & 'walk with' & instrument \\
\hline
\end{tabular}

Table 8: The applicative with intransitive verbs

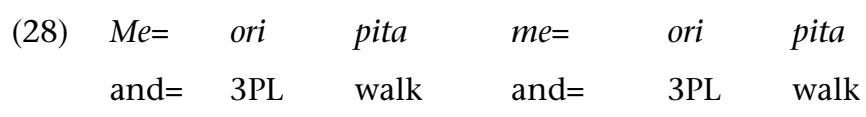

'And they walked and they walked.' [Aro. 1.69E]

(29) The goanna said to his friend who only had one leg, "I'll pull granny's leg off,

$\begin{array}{llllll}\text { ean } & \text { re }= & \text { paa } & \text { pita } & n i= & ] e \\ \text { 3SG } & \mathrm{CONJ}= & \mathrm{TAM} & \text { walk } & \mathrm{APP}= & 3 \mathrm{SG}\end{array}$

'so that you can walk with it."' [Aro. 5.20E]

With ditransitive verbs, however, the applicative reduces the verb's valency by requiring that the primary object either be deleted altogether, or removed from the core of the clause and made into an adjunct. Compare the applicative of hee $n i$, 'give s.th.', in (30) with the unmarked construction in (3). 
ULRIKE MOSEL

(30) E Davita [na $\underline{\text { hee }} \underline{\text { ni}}$ nao $]$ bene guu teve

ART David TAM give APP DIR ART pig PREP.3SG

te Vivite

PREP.ART Vivite

'David gave his pig to Vivite.' [Vos. 2.100R]

(3) E Toko [paa hee $]$ bene Sookara bona overe

ART Toko TAM give ART Sokara ART coconut

'Toko gave Sokara the coconut.' [Sia 1.68E]

In (30) the theme bene guu teve, 'his pig', is the object of a transitive clause while the recipient is an adjunct expressed by the prepositional phrase te Vivite, 'to Vivite'.

\begin{tabular}{|c|c|c|}
\hline hee & OBJ1 & $\mathrm{OBJ} 2$ \\
\hline 'give' & recipient & theme \\
\hline \multirow[t]{2}{*}{ hee ni } & OBJ1 & ADJUNCT \\
\hline & theme & recipient \\
\hline
\end{tabular}

Figure 1: Changing the valency of hee by using the applicative

When the speaker does not want to specify the recipient, he or she uses the transitive hee-ni-construction without the adjunct. In this case, as the following two examples illustrate, the recipient is not identifiable from the context: 
DITRANSITIVITY AND APPLICATIVE CONSTRUCTIONS IN TEOP - A CORPUS-BASED STUDY

(31) $A=$ maa iana bara maa meha taba

$\mathrm{ART}=\mathrm{PL}$ fish and PL other thing

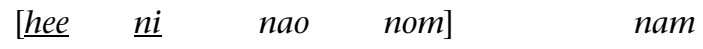

give APP DIR IMPF:1EXC.PL 1EXC.PL

'Fish and other things we gave.' [Pur. 2.272R]

(32) Eori koa o taba

3PL just ART thing

to [hee- hee $\underline{\text { hi }}$ roho $]$ ara nabunuu

REL RED- give APP before 1INC.PL in.the.olden.days

'These are the things that we used to give in the olden days.' [MLV. 2.27 $\mathrm{R}]$

Verbs that license a facultative secondary object behave like ditransitive verbs. If the recipient is not specified with a recipient-theme verb, the verb behaves like hee, 'give', and combines with the applicative. As a consequence the valency of VC becomes strictly transitive, with the theme as its object. Compare the applicative construction vaasusu ni, 'teach s.th.', below in (33) with the ditransitive constructions in $(13,14)$ and the unmarked transitive construction in (34) below:

(33) A tabae to [vaasusu ni ri=] ori teebona? ART what REL teach APP IMPF:3PL= 3PL there 'What do they teach there?' [Sii. 3.22R]

(34) E iaa $[$ na vaasusu bata= ri $]$ bona maa moon ART Mum TAM teach along= OBJ:3PL ART PL woman 'Mum was teaching the women.' [Sii. 1.587R]

A similar pattern is found in ditransitive patient-instrument constructions: 
(35) $a=$ maa meha nahu to [nahu- $\underline{\text { nahu }} \underline{\text { ni}}] \quad e$

$\mathrm{ART}=\mathrm{PL}$ other pot REL RED- cook APP 3SG

'the other pots that she cooked with' [Iar. 2.8R]

Note that the corpus does not provide any example in which the patient is expressed by an adjunct.

\begin{tabular}{|c|c|c|}
\hline nahu & OBJ1 & OBJ2 \\
\hline 'cook' & patient & instrument \\
\hline nahu ni & OBJ1 & *ADJUNCT \\
\hline 'use for cooking' & instrument & (not found) \\
\hline
\end{tabular}

Figure 2: Changing the valency of nahu, 'cook', by using the applicative

The next two examples illustrate that verbs such as bana, 'spread', (see Table 6) can enter either a ditransitive goal-theme construction or a transitive applicative construction with the theme as the object and the goal as an adjunct:

\begin{tabular}{|c|c|c|c|c|c|}
\hline [Bana] & $e$ & ta & kapa & bono & karirava \\
\hline spread & ART & piece & sheet.metal & ART & karirava leaf \\
\hline
\end{tabular}

'We spread the karirava leaf on the piece of sheet metal.' (lit. 'spread the sheet metal (with) leaves') [Hel. 1.29R]

'spread' bana

Figure 3: Changing the valency of bana, 'spread', by using the applicative 
DitRANSITIVITY AND APPLICATIVE CONSTRUCTIONS IN TEOP - A CORPUS-BASED STUDY

(37) A maamihu taba avuavuhu

ART all thing smell

$\begin{array}{llllllll}\text { kahi } & \text { bana } & n i & r i=] & \text { ori } & \text { te }= & a & \text { teebana } \\ \text { TAM } & \text { spread } & \text { APP } & \text { IMPF:3PL }= & \text { 3PL } & \text { PREP }= & \text { ART } & \text { bed }\end{array}$

'All kinds of scented leaves they will spread on the bed.' [Vos. 3.166R]

The ambitransitive verb hivi, 'ask', follows the same pattern. Compare (25) with (38):

(25) $E i$ [hivi vai $]$ anaa bono vaabuaku o hivi DEM ask now 1SG.OBJ ART second ART question

'Here, (she) then asked me the second question.' [Pur. 2.246R]

(38) $\mathrm{Me}=$ ori paa hivi bata ni $k=a n a a$

and $=3 P \mathrm{PL} \quad \mathrm{TAM}$ ask along APP $\mathrm{DAT}^{18}=1 \mathrm{SG} . \mathrm{OBJ}$

'And they asked about me.' [Pur. 2.318R]

It seems that any ditransitive construction can be changed into a transitive one by the use of the applicative. Even in the case of gono, 'get s.th. (with s.th.)', the corpus provides an example of an applicative construction, e.g. gono ni, 'use s.th. for getting (anything/things)'. Compare (39) with (26):

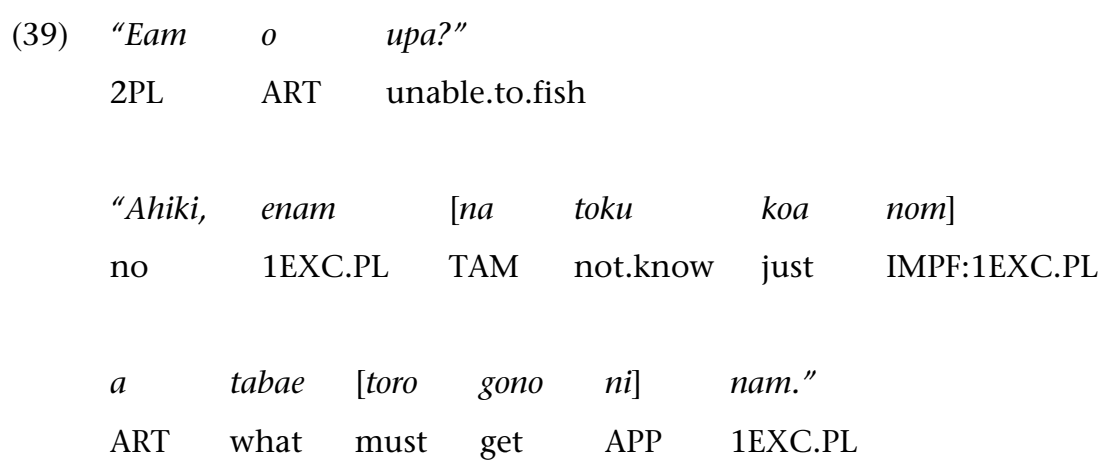

"“Are you unable to catch fish?" "No, we just don't know what we must use to get (some)"' [Sii 6.13-14R] 
The expression of the instrument's semantic role by the secondary object of a non-derived ditransitive verb seems to be unusual cross-linguistically (Andrej Malchukov, p.c.), but instruments as applied objects are common and are attested in a number of Oceanic languages (Evans 2003: 122-127). Incidentally, the loanword ius, 'use', is always used in an applicative construction:

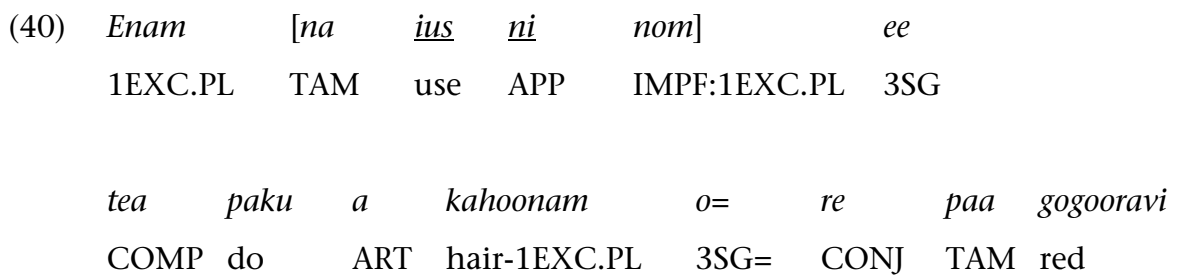

'We used it for doing our heads (i.e. hair) so that it would become red.' [Iar. 2.9R]

In sum, the applicative can change a ditransitive construction into a transitive one in which the object expresses the same semantic role as the secondary object in the ditransitive construction, whereas the referent of the original ditransitive primary object, i.e. the recipient, addressee, goal, theme or patient is not identified. To put it another way, in Teop bana, 'spread', implies a goal, vaasusu, 'teach', a recipient (of the teaching), nahu, 'cook', a patient, hivi, 'ask', an addressee, and gono, 'get', a theme. If the goal, recipient, patient, addressee, or theme is not identified, the VC must be marked by the applicative ni. The applicative forms of recipient-theme and goal-theme verbs such as hee ni, 'give s.th.', and bana ni, 'spread s.th.', can take an adjunct that expresses the recipient and goal respectively. 


\begin{tabular}{|l|l|l|}
\hline verb & in ditransitive constructions & in applicative constructions \\
\hline bana & 'spread s.th. (OBJ2) on s.th. (OBJ1)' & 'spread s.th.' \\
\hline gono & 'get s.th. (OBJ1) with the help of s.th.' & 'use for getting (things)' \\
\hline haihai & 'help s.o. (OBJ1) with s.th. (OBJ2)' & 'help with s.th.' \\
\hline hee & 'give s.o. (OBJ1) s.th. (OBJ2)' & 'give s.th.' \\
\hline hivi & 'ask s.o. (OBJ1) s.th. (OBJ2)' & 'ask s.th.' \\
\hline nahu & 'cook s.th. (OBJ1) with s.th. (OBJ2)' & 'cook with s.th.' \\
\hline vaasusu & 'teach s.o. (OBJ1) s.th. (OBJ2)' & 'teach s.th.' \\
\hline
\end{tabular}

Table 9: The applicative with ditransitive verbs

So far the valency of a verb such as nahu, 'cook', licenses four constructions: the intransitive, transitive, ditransitive and transitive applicative constructions. The next section on the incorporation of the preposition $k i$ will reveal two additional constructions.

\begin{tabular}{|l|l|l|l|}
\hline form & transitivity & patient & instrument \\
\hline nahu & intransitive & - & - \\
\hline nahu & transitive & + & - \\
\hline nahu & ditransitive & + & + \\
\hline nahu ni & transitive & - & + \\
\hline
\end{tabular}

Table 10: The valency of nahu, 'cook (s.th. with s.th.)', and nahu ni, 'cook s.th.'

If it is recoverable from the context, the primary object of ditransitive constructions may, like any other retrievable argument, be elided: 
(41) 'The next day, the woman went down and saw that one fish was missing, (she) ${ }^{19}$ only saw four. And (she) said, "Where did the other one go?" The woman went back. The man, in turn, went down to spear another one. (He) carried it home.'

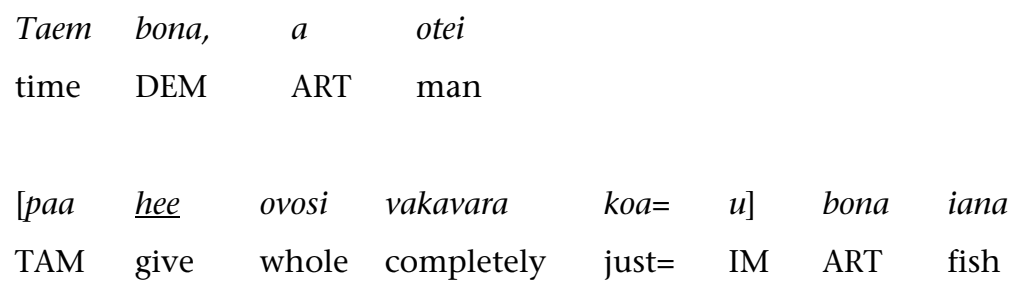

'This time, the man just gave (her) the fish completely whole.' [Ata. 1.63$71 \mathrm{R}]$

The implied specific recipient of hee, 'give', is the woman. The absence of a NP overtly referring to the woman has no impact on the ditransitive construction and the expression of the secondary object. Moreover, this ellipsis is not controlled by any syntactic rule in Teop. The preceding clause does not contain any reference to the woman that would control the ellipsis.

All applicative constructions - whether derived from intransitive or from ditransitive constructions - have in common that they are transitive. The applicative $n i$ cannot increase the valency of a transitive verb, but it combines with a number of transitive verbs, seemingly without any change in valency or meaning. Thus the verb pae, 'bury s.th.', is found with and without the applicative in the same kind of construction:

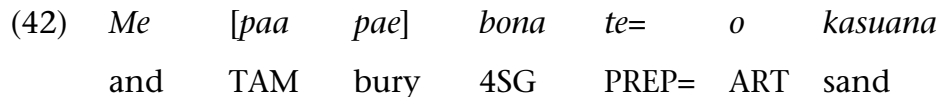

'And he buried it in the sand.' [Auv. 1.68R]

(43) Meve [paa pae ni] bona kasuana

and.3SG TAM bury APP 4SG on.the.beach

'And he buried it on the beach.' [San. 1.59E] 


\subsection{The incorporation of the preposition $k i$}

The preposition $k i$, 'for, to', can introduce adjuncts referring to a beneficiary, addressee or recipient, i.e. $k i$ can introduce animate roles, but not goals. The first example below (44) shows $k i$ as a preposition introducing an adjunct, and also nicely illustrates the use of the applicative with hee, 'give':

$(44)$

\begin{tabular}{|c|c|c|c|c|c|c|c|c|}
\hline OBJ & & VC & & & & SUBJ & & \\
\hline$O$ & toro & {$[n a$} & $\underline{\text { hee }}$ & $n i$ & maa & roho] & $a$ & New Zealand \\
\hline ART & ship & TAM & give & APP & DIR & before & ART & New Zealand \\
\hline
\end{tabular}

ADJUNCT beneficiary

$\begin{array}{llll}k i= & r i & \text { bono } & \text { lepa } \\ \text { DAT }= & \text { OBJ:3PL } & \text { ART } & \text { leper }\end{array}$

'The boat, New Zealand donated (it) to the lepers.' [Sii. 1.103-104R]

However, $k i$ can also be incorporated into the VC. When this happens, it licenses the object of a transitive clause or the primary object of a ditransitive clause denoting a beneficiary or a recipient: 


\begin{tabular}{|c|c|c|}
\hline & simple VC & VC with $k i$ \\
\hline beera & v.i., 'be the leader' & v.t., 'be the leader for s.o.' \\
\hline huahua & v.i., 'paddle' & v.t., 'paddle for s.o.' \\
\hline moroko & v.i., 'talk' & v.t., 'talk to s.o.' \\
\hline dee $m a a^{20}$ & v.t., 'bring s.th.' (45) & $\begin{array}{l}\text { v.dt., 'bring, give s.o. (OBJ1) s.th. } \\
(\mathrm{OBJ} 2)^{\prime}(46)\end{array}$ \\
\hline sue & v.t., 'say, tell s.th.' & $\begin{array}{l}\text { v.dt., 'tell s.o. (OBJ1) s.th. }(\mathrm{OB} J 2)^{\prime} \\
(47)\end{array}$ \\
\hline tasu & $\begin{array}{l}\text { v.dt., 'throw s.th. (OBJ2) at s.o. } \\
(\mathrm{OBJ} 1)^{\prime}(50)\end{array}$ & $\begin{array}{l}\text { v.dt., 'throw s.th. (OBJ2) for s.o. } \\
(\mathrm{OBJ} 1)^{\prime}(51)\end{array}$ \\
\hline gono & $\begin{array}{l}\text { v.dt., 'get s.th. (OBJ1) with s.th.' } \\
(\mathrm{OBJ} 2)(26)\end{array}$ & $\begin{array}{l}\text { v.dt., 'get s.o. (OBJ1) s.th. (OBJ2)' } \\
(52)\end{array}$ \\
\hline nahu & $\begin{array}{l}\text { v.dt., 'cook s.th. (OBJ1) with s.th.' } \\
(\mathrm{OBJ} 2)(22)\end{array}$ & $\begin{array}{l}\text { v.dt., 'cook s.th. (OBJ2) for s.o. } \\
(\mathrm{OB} / 1)^{\prime}(49)\end{array}$ \\
\hline paku & $\begin{array}{l}\text { v.dt., 'make s.th. (OBJ1) from } \\
\text { s.th.' (OBJ2) }\end{array}$ & $\begin{array}{l}\text { v.dt., 'make s.th. (OBJ2) for s.o. } \\
(\mathrm{OBJ} 1)^{\prime}\end{array}$ \\
\hline
\end{tabular}

Table 11: Incorporation of $k i$

A transitive VC with dee, 'carry', can be changed into a ditransitive VC by the incorporation of $k i$, which licenses a primary object denoting the recipient. Compare (45) and (46):

$\begin{array}{lllllll}\text { (45) Enaa } & {[p a a} & \underline{\text { dee }} & m a= & u] & e & \text { guu } \\ \text { 1SG } & \text { TAM } & \text { carry } & \text { DIR= } & \text { IM } & \text { ART } & \text { pig }\end{array}$

'I brought a pig.' [Mat. $1.78 \mathrm{E}$ ] 
DitRANSITIVITY AND APPLICATIVE CONSTRUCTIONS IN TEOP - A CORPUS-BASED STUDY

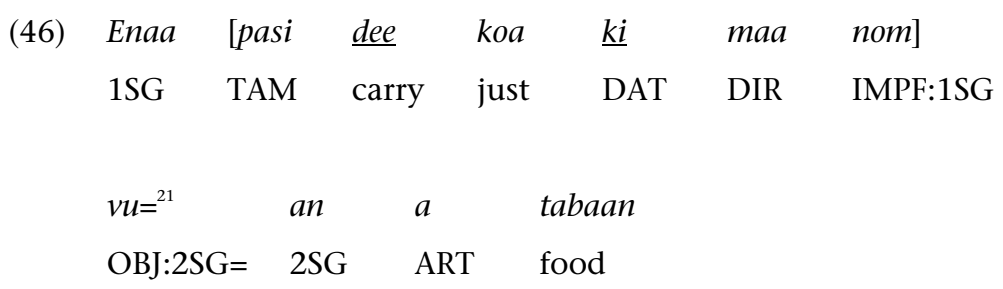

'I will just bring you the food.' [Aro. 14.16E]

Similarly, the transitive verb sue, 'say, tell s.th.', becomes ditransitive in combination with $k i$ and governs a primary object denoting the addressee, whereas the message is expressed by the secondary object.

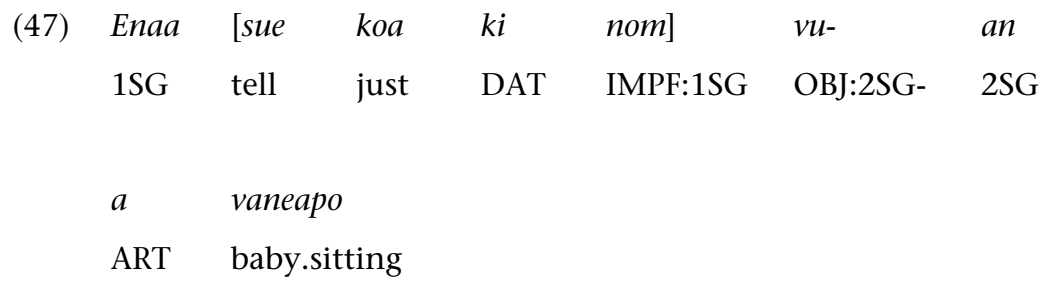

'I just told you to babysit.' (lit. 'the babysitting') [Siv. 1.61E]

When the ambitransitive verb nahu, 'cook', combines with $k i$, it can enter a transitive or ditransitive construction $(48,49)$. In both cases the (primary) object denotes the recipient of what is cooked.

$\begin{array}{lllll}\left.\text { (48) } \begin{array}{llll}\text { Eove to } \quad[n a h u \quad k i= & n a\end{array}\right] & \text { bona } \\ \text { 3SG REL cook } \quad \text { DAT }= & \text { IMPF:3SG } & \text { 4SG } \\ \text { 'He is the one who cooks for him.' [Mah. 2.77R] } & \end{array}$

While in the transitive construction (48) the patient (i.e. what is cooked) is not specified, it is expressed by a secondary object in the ditransitive clause $(49)^{22}$ :

$\begin{array}{llllllll}\text { (49) Enaa } & \text { tau } & \text { nahu } & \text { ki- } & e & \text { iaa } & \text { bono } & \text { paapoo } \\ \text { 1SG } & \text { TAM } & \text { COOK } & \text { DAT } & \text { ART } & \text { Mum } & \text { ART } & \text { greens }\end{array}$

'I must cook the greens for Mum (who has just given birth and must eat greens).' [Aro. 6.19E] 
The following two examples illustrate the contrast between an unmarked ditransitive construction (50) and a ditransitive construction marked by the incorporation of $k i$ (51). In (50) the primary object refers to the goal and the secondary object to the theme:

\begin{tabular}{|c|c|c|c|c|c|c|}
\hline (50) & {$[$ tasu } & $m a a]$ & bene & sinanae & bona & vaakokopao \\
\hline TAM & throw & DIR & ART & his.mother & ART & vaakokopao \\
\hline
\end{tabular}

'(he) threw the vaakokopao fruit at his mother.' [Nan. 3.132R]

The example (50) comes from a legend where a boy is hiding in a vaakokopao tree. When he sees his mother, he picks a fruit and throws it at his mother to attract her attention. The next example (51) is taken from a similar context. But here a monkey throws a fruit down from a tree for his friend to eat. The target is now a recipient/beneficiary, and accordingly the VC is marked by $k i$ :

$\begin{array}{llrlrll}\text { (51) } & \text { Moogee } & {[\text { paa }} & \text { tasu } & \text { gunaha } & \text { ki }] & \text { bona } \\ \text { and } & \text { Monkey } & \text { TAM } & \text { throw } & \text { down } & \text { DAT } & 4 \text { SG } \\ \text { bono } & \text { peho } & \text { vua } & & & & \\ \text { ART } & \text { one } & \text { fruit } & & & & \end{array}$

'And Monkey threw a fruit down for him.' [Ter. 1.13E]

The fact that the recipient/beneficiary in (51) is expressed by a different construction, i.e. by the incorporation of $k i$, suggests that goal and recipient/beneficiary are two distinct semantic roles in Teop.

Our last example is gono, 'get s.th.'. When combined with $k i$, it takes a recipient as its primary object and the theme as its secondary object, and thus behaves like nahu ki, 'cook s.o. s.th.'. 
DitRANSITIVITY AND APPLICATIVE CONSTRUCTIONS IN TEOP - A CORPUS-BASED STUDY

(52) ean re [gono $k=\quad a \quad m a-\quad r a-]$

2SG CONJ get DAT $=$ OBJ- DIR- OBJ:1INC.PL $=$

ara na naono

1INC.PL some wood

'so that you get us some wood.' [Aro. 7.19.E]

\begin{tabular}{|ccc|}
\hline gono & OBJ1 & OBJ2 \\
gono $k i$ & OBJ1 & OBJ2 \\
& recipient & theme \\
\hline
\end{tabular}

Figure 4: Changing the valency of gono, 'get', by the incorporated preposition $k i$

\subsection{Multiple valency change}

We have not yet investigated multiple valency change in detail, but we would like to draw the attention to the fact that transitive VCs can be intransitivised by object incorporation (53) or by the anticausative prefix $t a-(54,55,56)$, and then transitivised by the applicative $(53,54)$ or $k i(55,56)$ :
(53) asun
v.t./v.dt., 'kill s.o. (with s.th.)'
asun $a b a$
v.i. (with object incorporation), 'kill (people)'
asun aba ni
v.t. 'use s.th. for killing (people)'
(54) gune
v.t., 'wake s.o. up'
tagune
v.i., 'wake up'
tagune ni
v.t., 'wake up because of s.th./by s.th.'
(55) paku
v.t./v.dt., 'do, make s.th. (from s.th.)'
tapaku
v.i., 'happen, be done'
tapaku ki
v.t., 'be done for s.o.' 
ULRIKE MOSEL

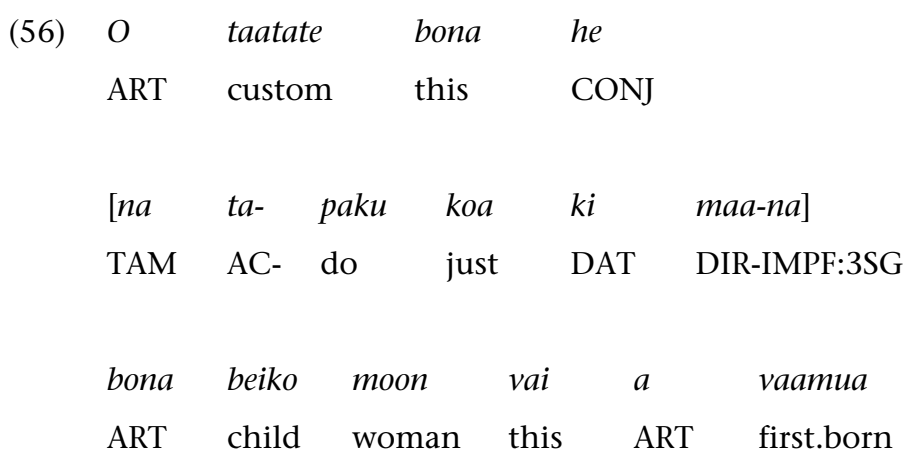

'This custom was practised only for the first-born girl.' [Nan. 2.2E]

The valency of ditransitive verbs can be reduced by the applicative and then transitivised by a serial verb. Example (57) shows this with the ditransitive goaltheme verb koma, 'pour s.th. on s.th.':

(57) 'When you have finished crushing the galip nuts,

$\begin{aligned} & \text { koma }= \\ & \text { 3 }\end{aligned}$ bona
pour $\quad$ ruene
pour the water on them.' [Hel. 2.19R]

When koma, 'pour s.o. s.th.', is combined with the applicative ni the theme becomes the direct object while the goal can be omitted or expressed by an adjunct:

\begin{tabular}{|c|c|c|c|c|c|}
\hline \multirow[t]{3}{*}{ (58) } & $\begin{array}{l}A= \\
1 \mathrm{INC} . \mathrm{PL}=\end{array}$ & $\begin{array}{l}\text { re } \\
\text { then }\end{array}$ & $\begin{array}{l}\text { paa } \\
\text { TAM }\end{array}$ & $\begin{array}{l}\text { koma } \\
\text { pour }\end{array}$ & $\begin{array}{l}n i= \\
\mathrm{APP}=\end{array}$ \\
\hline & $t e=$ & $a$ & kaukau & & \\
\hline & PREP= & ART & sweet p & ato & \\
\hline
\end{tabular}

'Then we pour it (the coconut oil) over the sweet potatoes.' [Hel. 3.27R]

Now the applicative construction koma ni, 'pour s.th.', can take a serial verb that changes the transitive construction into a ditransitive one. Note that the serial 
verb precedes the applicative, since all lexical modifiers follow the nucleus of the verb complex and precede postnuclear grammatical elements:

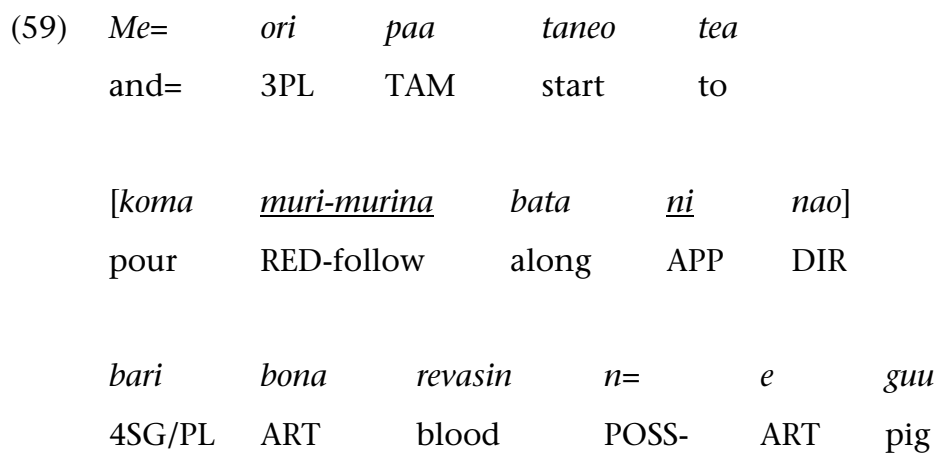

'And they started pouring the pig's blood behind him.' [Aro. 7.122E]

In (59) the serial verb murimurina, 'follow', increases the valency of the VC koma $n i$, 'pour s.th.', by adding the goal argument bari, 'him', which takes the position of the primary object so that the theme bona revasin ne guu, 'the blood of the pig', becomes the secondary object.

\section{SUMMARY AND CONCLUDING REMARKS}

On the basis of the semantic roles of primary and secondary objects, unmarked ditransitive clauses can be divided into four classes (section 6.):

\begin{tabular}{|l|l|l|}
\hline & primary object & secondary object \\
\hline I & recipient (also addressee) & theme (also message) \\
\hline II & goal (where s.th. is put or thrown) & theme \\
\hline III & patient & instrument \\
\hline IV & theme & instrument \\
\hline
\end{tabular}

Table 12: Classes of unmarked ditransitive clauses

This distribution of the semantic roles in unmarked ditransitive clauses suggests that the selection of a particular participant as a primary or a secondary object is not arbitrary: 
- The recipient, goal and patient always function as primary objects.

- The instrument always functions as the secondary object.

- The theme occurs in the primary object function only when the other participant is an instrument.

Thus the expression of a particular participant as a primary object is controlled by a hierarchy, which we call the ditransitivity hierarchy:

(60) recipient/goal > patient/theme $>$ instrument

The left-most participant in the hierarchy is expressed by the primary object, the others by the secondary object. The recipient, goal and patient have in common that - unlike the theme and the instrument - they do not imply any movement. The table below shows how the four classes of unmarked ditransitive clause patterns (see table 6) relate to the ditransitivity hierarchy:

\begin{tabular}{|lll|l|l|l|l|l|}
\hline & & & recipient & goal & patient & theme & instrument \\
\hline 1 & hee & 'give' & OBJ1 & - & - & OBJ2 & - \\
\hline 2 & tasu & 'throw' & - & OBJ1 & - & OBJ2 & - \\
\hline 3 & nahu & 'cook' & - & - & OBJ1 & - & OBJ2 \\
\hline 4 & gono & 'get' & - & - & - & OBJ1 & OBJ2 \\
\hline
\end{tabular}

Table 13: Unmarked ditransitive clause patterns

The valency of the VC can be different from that of the verbal nucleus in that it can incorporate valency-changing elements such as an incorporated object $(53)^{23}$, a serial verb $(2,58)$, and the applicative particle $(29-33,35,37-39,44,51$ $54,58-59)$ or a preposition $(46-49,51-52,55-56)$. In this paper we have examined only the applicative $n i$ and the preposition $k i$.

When used with intransitive verbs, the applicative increases the valency of the VC (section 7.1.). The applied object can be the patient of an action, the theme of a movement (30-32), the content/message of an act of communication (33, 38 ), the cause of a process, the stimulus of an emotion (table 8), or the instrument of an action $(29,35,39)$. 
With strictly ditransitive verbs such as hee, 'give s.o. s.th.', the applicative reduces the valency of the VC either by deleting the primary object $(31,32)$ or by demoting it to the status of an adjunct (30). Ambitransitive verbs such as $n a h u$, 'cook (s.th. with s.th.)', behave like strictly ditransitive verbs. If only the referent of the secondary object, i.e. the theme or the instrument, is to be expressed, ambitransitive verbs take the applicative so that the VC becomes transitive $(33,35,39)$. Theme VCs such as hee ni, 'give s.th.', and tasu ni, 'throw s.th.', may take an adjunct referring to the recipient (30) and the goal (37) respectively, whereas the patient is never expressed by an adjunct.

\begin{tabular}{|l|l|l|l|}
\hline & & theme & instrument \\
\hline hee $n i$ & 'give s.th.' & OBJ & - \\
\hline tasu ni & 'throw s.th.' & OBJ & - \\
\hline nahu ni & 'use s.th. for cooking' & - & OBJ \\
\hline gono $n i$ & 'use s.th. for getting things' & - & OBJ \\
\hline
\end{tabular}

Table 14: Applicative transitive clause patterns

The corpus also shows a number of verbs that can take the applicative in transitive clauses without changing their valency, e.g. pae (ni), v.t., 'bury s.th.' $(42,43)$.

In contrast to the applicative, the incorporation of the preposition $k i$ only increases the valency of the VC (section 7.2.). With intransitive verbs, the VC becomes transitive and licenses an object that denotes a beneficiary or an addressee, e.g. huahua $k i$, 'paddle for s.o.', moroko ki, 'talk to s.o.'

When transitive verbs combine with $k i$, the $\mathrm{VC}$ becomes ditransitive and governs a primary object that denotes a recipient or an addressee, whereas the original object becomes the secondary object. 


\begin{tabular}{|l|l|l|l|}
\hline & & recipient/addressee & theme/message \\
\hline dee maa & 'bring s.th.' & - & OBJ \\
\hline sue & 'say, tell s.th.' & - & OBJ \\
\hline dee maa ki & 'bring s.o. s.th.' & OBJ1 & OBJ2 \\
\hline sue ki & 'tell s.o. s.th.' & OBJ1 & OBJ2 \\
\hline
\end{tabular}

Table 15: Ditransitivisation by $k i$

With ditransitive verbs, $k i$ rearranges the clause pattern in line with the ditransitivity hierarchy: $k i$ always licenses a new primary recipient or beneficiary object and removes the original primary object from this position. The primary object of goal-theme verbs such as tasu, 'throw s.th. at s.o./s.th.', is replaced by the recipient object, whereas the theme retains the secondary object function. Compare table 13 with table 16.

\begin{tabular}{|l|l|l|l|l|l|l|}
\hline & & recipient/beneficiary & goal & patient & theme & instrument \\
\hline $\begin{array}{l}\text { *hee } \\
k i\end{array}$ & ('give') & - & - & - & - & - \\
\hline $\begin{array}{l}\text { tasu } \\
k i\end{array}$ & $\begin{array}{l}\text { 'throw s.th. } \\
\text { for s.o.' }\end{array}$ & OBJ1 & - & - & OBJ2 & - \\
\hline $\begin{array}{l}\text { gono } \\
k i\end{array}$ & $\begin{array}{l}\text { 'get s.th. for } \\
\text { s.o.' }\end{array}$ & OBJ1 & - & - & OBJ2 & - \\
\hline $\begin{array}{l}\text { nahu } \\
k i\end{array}$ & $\begin{array}{l}\text { 'cook (s.th.) } \\
\text { for s.o.' }\end{array}$ & OBJ1 & - & OBJ2 & - & - \\
\hline $\begin{array}{l}\text { paku } \\
k i\end{array}$ & $\begin{array}{l}\text { 'do s.th. for } \\
\text { s.o.' }\end{array}$ & OBJ1 & - & OBJ2 & - & - \\
\hline
\end{tabular}

Table 16: Ditransitive clause patterns with $k i$ incorporation

But with patient-instrument or theme-instrument verbs, the new recipient demotes the patient or theme to the status of a secondary object and ousts the instrument from the core of the clause. 
The differing impact of $k i$-incorporation on goal-theme verbs and patientinstrument or theme-instrument verbs demonstrates that recipient and goal, on the one hand, and patient and theme, on the other, form pairs of closely related, though distinct semantic roles.

In spite of its obvious limitations, the corpus of the Teop language documentation seems to be sufficient to identify clause patterns and reveal the mechanisms of valency change. This analysis of the semantic role structure of simple and derived constructions shows that most of the traditional semantic roles examined here are syntactically relevant in the sense that they are distinguished from each other by formal means of expression. The only exceptions are the addressee and the message, which formally do not differ from the recipient and the theme, and hence are regarded as metaphorical extensions of these.

\section{REFERENCES}

Ágel, Vilmos (2000), Valenztheorie, Tübingen: Gunter Narr Verlag.

Ágel, Vilmos, Ludwig M. Eichinger, Hans Werner Eroms, Peter Hellwig, Hans Jürgen Heringer, Henning Lobin (2003) (Hgg.), Dependenz und Valenz/Dependency and Valency, HSK 25.1, Berlin/New York: Mouton de Gruyter.

Aikhenvald, Alexandra Y. (2006), "Serial Verb Constructions in Typological Perspective", in: Aikhenvald, Alexandra Y., Robert M. W. Dixon (2006) (eds.), Serial Verb Constructions. A Ccross-linguistic Typology, Oxford: Oxford University Press, pp. 1-68.

Biber, Douglas, Stig Johansson, Geoffrey Leech, Susan Conrad, Edward Finegan (1999), Longman Grammar of Spoken and Written English, Harlow, Essex: Pearson Education Limited.

Dik, Simon C. (1989), The Theory of Functional Grammar, Part I, The Structure of the Clause, Dordrecht: Foris Publication.

Dixon, R. M. W., Alexandra Aikhenvald (2000), "Introduction", in: Dixon, R. M. W., Alexandra Aikhenvald (2000) (eds.), Changing Valency. Case Studies in Transitivity, Cambridge: Cambridge University Press, pp. 1-29.

Dudenredaktion (2005), Duden. Die Grammatik, Mannheim, Leipzig, Wien, Zürich: Dudenverlag.

Engel, Ulrich (2002), Kurze Grammatik der deutschen Sprache, München: Iudiciumverlag.

Evans, Bethwyn (2003), A Study of Valency-changing Devices in Proto-Oceanic, Pacific Linguistics 539, Canberra: The Australian National University. 
Foley, William A., Robert D. Van Valin (1984), Functional Syntax and Universal Grammar, Cambridge: Cambridge University Press.

Helmbrecht, Johannes (1998), Universalität und Vagheit semantischer Funktionen, München: Lincom Europa.

Herbst, Thomas (2004), "Valency Theory and the Valency Dictionary of English. A Few Remarks on the Linguistic and Lexicographical Principles", in: Herbst, T., D. Heath, I. F. Roe (2004) (eds.), A Valency Dictionary of English. A Corpusbased Analysis of the Argumentation Patterns of English Verbs, Nouns and Adjectives, Berlin: De Gruyter, pp. xxiii-xlii.

Kroeger, Paul R. (2005), Analyzing Grammar, Cambridge: Cambridge University Press.

Lazard, Gilbert (1998), Actancy, Berlin/New York: Mouton de Gruyter.

Lehmann, Christian (1992), "Valenz", in: Anschütz, Susanne (1992) (Hg.), Texte, Sätze, Wörter und Moneme. Festschrift für Klaus Heger zum 65. Geburtstag, Heidelberg: Orient Verlag, pp. 435-454.

Margetts, Anna (2007), "Three-participants Events in Oceanic Languages", Oceanic Linguistics, 46 (2007), pp. 71-127.

Mosel, Ulrike (1991), "Towards a Typology of Valency", in: Seiler, Hansjakob, Waldfried Premper (1991) (Hgg.), Partizipation. Das sprachliche Erfassen von Sachverhalten, Tübingen: Gunter Narr Verlag, pp. 240-251.

Mosel, Ulrike with Yvonne Thiesen (2007), Teop Sketch Grammar, www.mpi.nl/DOBES/projects/teop

Mosel, Ulrike, Roslyn Purupuru, Alexander Radtke, Jessika Reinig, Ruth Saovana Spriggs, Marica Schwartz, Yvonne Thiesen (2007), The Teop Language Corpus, www.mpi.nl/DOBES/projects/teop

Mosel, Ulrike (in print), "The Fourth Person in Teop", in: Bowden, John, Nikolaus P. Himmelmann (in print), A Journey through Austronesian and Papuan Linguistic and Cultural Space. Papers in Honour of Andrew K. Pawley, Canberra: Pacific Linguistics.

Mosel, Ulrike (submitted), "Analogical Levelling across Constructions Incorporated Prepositions in Teop", in: Lehmann, Christian, Stavros Skopeteas (eds.) (in prep.), The Evolution of Grammatical Relations.

Naess, Ashild (2007), Prototypical Transitivity, Amsterdam: John Benjamins Publishing Company.

Reinig, Jessika (2004), "Serial Verb Constructions in Teop (North Bougainville)", in: Bril, Isabelle, Françoise Ozanne-Rivierre (2004) (eds.), Complex Predicates in Oceanic languages. Studies in the Dynamics of Binding and Boundness, Berlin, New York: Mouton de Gruyter, pp. 89-106.

Ross, Malcolm (1988), Proto-Oceanic and the Austronesian Languages of Western Melanesia, Canberra: Pacific Linguistics.

Storrer, Angelika (1992), Verbvalenz, Tübingen: Niemeyer.

Talmy, Leonard (2007), "Lexical Typologies", in: Shopen, Timothy (2007) (ed.), Language Typology and Syntactic Description, Cambridge: Cambridge University Press, pp. 66-168. 
Tesnière, Lucien (1959), Éléments de syntaxe structurale, Paris: Klincksieck.

\section{NOTES}

1 I wish to thank Geoffrey Haig and the two anonymous reviewers for their critical comments, pointing out errors and offering helpful suggestions. Thanks are also due to Roslyn Purupuru, Jessika Reinig, Marcia Schwartz, Ruth Spriggs and Yvonne Thiesen for their cooperation in compiling the Teop Language Corpus and the Teop Lexical Database, which was generously funded by the Volkswagen Foundation from 20002007.

2 The exact classification is given by Ross (1988: 25, 213-128): Oceanic, Western Melanesian, Meso-Melanesian Cluster, North-West-Salomonic, Nehan/North Bougainville, Saposa-Tinputz.

3 Historically the applicative particle $n i$ is the reflex of the Proto-Melanesian suffix ${ }^{*}=n i$, which transitivises intransitive verbs by promoting an adjunct to the position of an object (Evans 2003: 150-156, 233).

4 See Mosel/Thiesen (2007), § 6.9 for prepositions, § 8.3. for object incorporation and § 8.5. for serial verb constructions.

5 Due to limited time and space, it is not possible to discuss our findings in view of valency changing devices in related languages and Proto-Oceanic (Evans 2003) or in view of current theories on argument structure.

6 Typical examples are vaa-ani v.dt., 'give s.o. s.th. to eat', and vaa-huvi 'help s.o. peel s.th.'.

7 The square brackets indicate the boundaries of the VC.

8 Abbreviations in the glossing: 4SG singular object pronoun that is used when the subject is a third person, 4SG/PL object pronoun that refers to a single entity when the subject is 3PL, or to a plural entity irrespective of the number of a third person subject, AC anticausative, ART article, CAUS causative, COMP complementiser, CONJ conjunction, DAT the preposition $k i$, DEM demonstrative, DIR directional particle, EXC exclusive, IM a postverbal tense/aspect marker that indicates immediateness, IMPF imperfective aspect marker that inflects for person and number, INC inclusive, OBJ object marker, PL plural, SG singular, RED reduplication, REL relative pronoun, TAM preverbal tense/aspect/mood marker.

9 The abbreviations in square brackets refer to the Teop Language Corpus. R stands for recordings that are only accessible on request, $\mathrm{E}$ for open resources; see www.mpi.nl/DOBES/projects/teop

10 For a detailed analysis of the flaws of such tests see Storrer (1992, in particular pp. 75 $87,116,162-164,223-225,234-238,240-245,253-256)$, a brief summary is given in Ágel (2000: 172-176).

11 Biber et al. (2004: 142-144) lists 14 clause patterns for English. For German the figures vary between 53 (Engel 2002: 29) and 34 (Dudenredaktion 2005: 939-940).

12 The pronoun bari denotes singular and plural objects when the subject of the clause is a third person. It is called a $4^{\text {th }}$ person pronoun for reasons that are explained in Mosel (2007: § 6.6.), and Mosel (in print).

13 The VC consists of dao ri, but the imperfective aspect marker ri-forms a phonological word with the following pronominal subject ori 'they'.

14 Though only if the subject does not rank lower on the person hierarchy $1 / 2>3$, which is usually the case. Otherwise the imperfective aspect marker agrees with the object, see Mosel (2007: § 9.3.). 
15 The term primary object covers here both objects of transitive clauses and primary objects in ditransitive clauses.

16 The pronoun anaa is analysed as $a$-naa, with the object marker $a$-being prefixed to the pronominal stem.

17 One of the referees remarks that gono v.dt. 'get s.th. with s.th. (an instrument)', is a verb of obtaining rather than a verb of movement and that it is "questionable whether 'theme' is the right label for the role of the object in this case." I cannot answer this question at the moment.

18 When a first or second person pronoun functions as the object of an applicative construction, it is marked by the preposition $k i / k$ - which we gloss as DAT because of its functional similarity with a dative case marker.

19 The brackets indicate that this argument is ellipsed.

20 When dee, 'carry', is combined with the directional marker maa, 'hither', it means 'bring s.th.'.

21 Here and below in (47) the 2SG object marker is outside the VC and prefixed to the pronoun. But there are also forms with the object marker inside the VC, see (18) and (23), compare note 16.

22 Note that ki in tau nahu ki=e iaa, 'cook for Mum', belongs to the VC as an incorporated preposition. The sequence $k i=e$ iaa is not a prepositional adjunct because it follows directly the VC. As an adjunct it would follow the patient argument bono paapoo, 'the greens'. Furthermore, bono paapoo, 'the greens', is marked by the object article bono which indicates that it is preceded by a third person argument. Since enaa, ' $\mathrm{I}$ ', is a first person argument, this third person argument must be $e$ iaa, 'Mum'. Put differently, if kie iaa, 'for Mum', were an adjunct, the article of paapoo, 'greens', would be the basic article $o$ rather than the object article bono according to the article selection rule.

23 See Mosel (2007: § 8.3.) for incorporated nouns, (2007: § 8.5.) for serial verbs, and (2007: § 6.9.) for incorporated prepositions; and Mosel (submitted) for a historical treatment of the incorporation of prepositions. 